\title{
sciendo REIMBURSEMENT OF EXCISE DUTY ON MINERALS OILS
}

DOI 10.2478/ntpe-2018-0024

dr hab. inż. Marek Jaśkiewicz, prof. PSk. Kielce University of Technology, Poland Ing. Juraj Hammer

doc. Ing. Miloš Poliak, PhD. University of Zilina, Slovak Republic dr hab. inż. Dariusz Więckowski Automotive Industry Institute, Poland

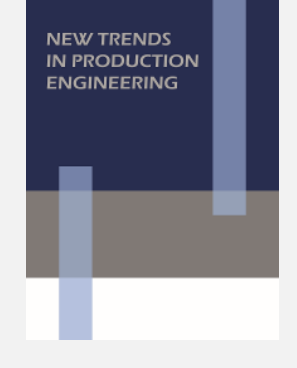

2018

Volume 1

Issue 1

pp. 191-196

\begin{abstract}
Enterprise in the EU is currently a single market business, but on which the conditions are not completely unified. In the case of mineral oil excise duty a minimum level of taxation is set by EU rules, but individual states do not strictly prescribe a specific rate of tax. It is a fact for international road transport, that there are states on the route of transport, where it is preferable to pump fuel. Because the mineral oil tax is an income of state budget in concrete state, is good for the state, if the carrier pumps fuel on the territory of that state. For carriers who only drive within the country the higher tax rate is more advantageous in terms of choice. For this reason, some EU countries apply for the selected group of entrepreneurs, the refund of excise duty due to the use of carriers in their territory and to achieve higher tax deduction in cumulative terms. The purpose of this contribution is to identify the possibilities for refunding excise duty in the Slovak Republic and to propose a procedure for assessing the effects of the refund of excise duty on mineral oils.
\end{abstract}

Keywords: mineral oils, reimbursement, excise duty, taxes, freight transport

\section{INTRODUCTION}

Enterprise in the EU is currently a single market business, but not all the conditions in the tax area are fully unified, which also applies to mineral oil excise duty. In the case of mineral oil excise duty, the EU minimum is set by the EU rules for diesel fuel at level $330 €$ on 1000 liters (Angelo, 1995). Individual EU member states, as they do not strictly prescribe a specific rate, may set any tax amount above this level. It is a fact for international road transport, that there are states in the transport route where it is preferable to use fuel. Since excise duty is the revenue of a state's, state budget it is beneficial for the state if the carrier pumps fuel in territory of that state. For carriers who only drive within the country, the higher tax rate is more favorable from the point of view of tax collection (Balko \& Kralik, 2005). For this reason, some EU countries apply excise tax rebate for selected businesses to encourage the use of fuel by carriers in their territory and to achieve higher tax deduction in cumulative terms (Brzezinski et al., 1998). The research itself will be focused on refundation which represents the return of part of the excise duty rate to the carrier, which was paid in the form of a fuel price and which is transferred to the state budget. We will look at the optimal solution to the level of excise duty, but it must be set to bring the desired effect for both parties for carries, but also for state. By creating favorable conditions, the Slovak carriers would pump larger volumes of fuel in Slovakia. Such conditions would also attract foreign carriers, who would buy fuel in the Slovak Republic during transit through the Slovak Republic, thereby increasing the amount of fuel consumed, from which excise duty is payable. It means, the aim of this paper is to identify the possibilities for reimbursement of excise duty in the Slovak Republic and to propose a procedure for assessing the effects of the refund of excise duty on mineral oils.

\section{ANALYSIS OF EXCISE DUTY ON MINERAL OILS}

Among excise taxes the excise duty on mineral oils has the greatest impact on the costs associated with the road transport business. This excise duty is somewhat limited by the EU by Council Directive 2003/96/EC of 27 October 2003 on the restructuring of the legal 
community for the taxation of energy products and electricity, which sets a minimum rate of excise duty on diesel fuel from 1 January 2010 to $330 € / 1000$ liters (Merino \& Arroyo, 2001). The SR applies a tax of $368 €$ per 1000 liters for diesel fuel and for petrol, $514 €$ per 1000 liters. In Figure 1, we can see what percentage of the amount of funds in the state budget is the excise duty on mineral oils among all excise taxes its share is the highest with the ratio of all watched, with a value of $53 \%$ (Faria, 1995).

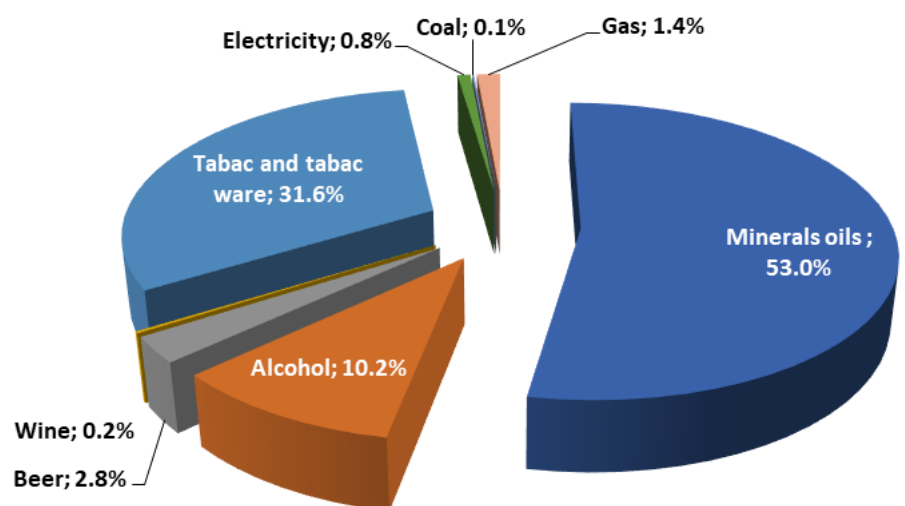

Source: processed by the authors

\section{FUEL CONSUMPTION ANALYSIS THROUGH EXCISE DUTY REIMBURSEMENT}

Fuel consumption by the state, through the adjustment of excise duties can be supported in several ways, by reducing the rate of excise duty to the minimum required level of $330 € / 1000$ I, introducing so-called "professional diesel", or by reimbursement of excise duty on mineral oils (Kubatova, 2006). The latest way to reduce excise taxes, in the form of a refund of the mineral oil taxis a way of reducing costs that is already in place in some EU countries particularly in Slovenia, France, Belgium, Spain, Hungary and Italy (Kosikowski, 2003). Refunds are governed by national laws and the purpose of reimbursing excise duty on mineral oils is to promote the use of fuel in a concret country, by a carrier established in a foreign country. In general, a portion of excise duty exceeding $330 €$ per 1000 liters is refunded of diesel fuel (Poliak \& Poliakova, 2015). Because of the fact, that there is no unified single country level of excise duty within the EU, it causes a different final price of fuel, which in international transport, in the efforts of carriers to reduce their costs, causes fuel to be pumped abroad, in countries with a lower fuel price. Taking into account facts such as the volume of fuel tanks of semi-trailers, which are in the range of 370 to 1300 liters it is possible to carry out transport across the EU for on one fuel pump, approximately at a consumption of 32 I per 100 $\mathrm{km}$ in a semi-trailer with a total permissible weight of 40 tonnes (Walters, 1968). Table 1 also summarizes the periodicity of the application for refund by the transport company and it is also a summary of the actual reimbursement date and the deadline set by the relevant legislation for that state (Gnap et al., 2003).

Table 1.

The summary table of countries with refunds applied.

\begin{tabular}{|l|c|c|c|c|}
\hline \multicolumn{1}{|c|}{ State } & $\begin{array}{c}\text { Application } \\
\text { period }\end{array}$ & $\begin{array}{c}\text { Payout term } \\
\text { determined } \\
\text { by legislation } \\
\text { (month) }\end{array}$ & $\begin{array}{c}\text { Actual payout } \\
\text { date (month) }\end{array}$ & $\begin{array}{c}\text { Max. refund. } \\
\text { value in } € / /\end{array}$ \\
\hline Slovenia & Monthly, Half of year Year & $1.5-2$ & $3-5$ & 0.0844 \\
\hline France & Half of year & $3-4$ & $4-5$ & 0.0451 \\
\hline Belgium & Monthly, Half of year Year & $4-5$ & 8 & 0.0813 \\
\hline Spain & Quarter of year & 1 & $3-4$ & 0.029 \\
\hline Hungary & Quarter of year Year & - & - & 0.072 \\
\hline Italy & Monthly Year & - & - & 0.1899 \\
\hline
\end{tabular}

Source: processed by the authors 
PROPOSAL FOR REFUND, RESEARCH CARRIED OUT ON THE BASIS OF SUPPORT FOR THE USE OF FUEL IN THE TERRITORY OF THE SLOVAK REPUBLIC

Promote business in road transport in the Slovak Republic and Slovak carriers are possible, as mentioned above, in several ways. Firstly, it is a total reduction in excise duty to the minimum threshold set by the European Union, or the introduction of professional diesel, or already introduced cost-cutting in some EU countries, through the refund of excise duty on mineral oils (Frumkin et al., 2004). On the basis of analysis and research is such a way of reducing costs can be considered very advantageous and on the part of the carriers, when their costs are reduced, but also by the state side. The State by introducing an excise tax rebate from the part will lose funds from selecting the full amount of excise duty, but with the correct height adjustment of rate, which would return to the carrier, the Slovak Republic would become more attractive for Slovak and foreign carriers from the point of view of diesel fuel prices, which could again increase the funds flowing into the state budget, just from excise taxes.

The proposal for the application of the refund of excise duty on mineral oils in the Slovak Republic is processed under the following basic conditions:

- The fuel must be pumped at petrol stations in the territory of the Slovak Republic.

- This fuel will be used for trucks weighing over 7.5 tonnes.

- The fuel must be paid through the fuel card, issued on the relevant national vehicle registration number.

- The carrier must be registered for VAT payment.

- Current excise duty on mineral oils for diesel fuel in Slovakia: $368 € / 1000$ ।

- The EU-wide minimum duty rate for mineral oil fuel duty: $330 € / 1000 \mathrm{I}$.

- Suggested refund rate for SR: $38 € / 1000$ I

Suggested refund amount, which could be implemented into national laws by SR would be the difference between the amount of the minimum rate of the EU Directive of value $330 € / 1000$ I and the current established tax rate in the Slovak Republic for value $368 € / 1000$ I.

The Slovak Republic would reach the minimum required level and would gain a competitive advantage over countries with a higher tax rate on diesel fuel. Among the neighboring countries, it would be at least equal to the excise limit in Poland, where Poland is the largest competitor for the SR, as can be seen in Figure 2 (Ayala et al., 2010).

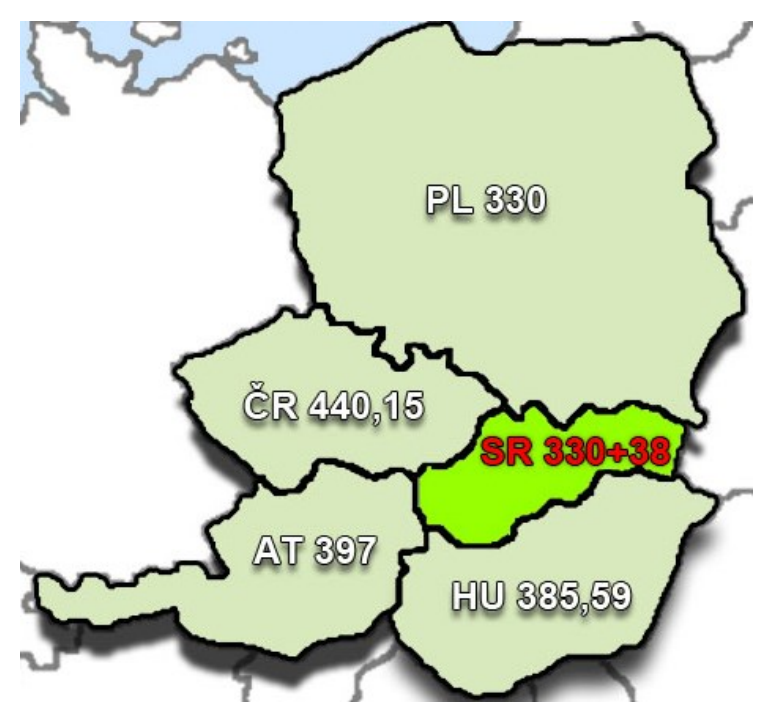

Fig. 2. Comparison of excise duty on diesel at the introduction of a refund in the SR. Source: processed by the authors

Types of carriers who pump fuel in the Slovak Republic:

- Slovak carriers operating domestic freight road transport, who purchase the fuel exclusively in the Slovak Republic,

- Slovak carriers operating both domestic and international road freight transport, who buy some of the fuel in Slovak Republic but also abroad, 
- the last group of carriers is foreign carriers, performing international road freight transport, who also pump part of the fuel in the Slovak Republic.

In order to reduce excise duty on mineral oils, in the form of a refund, increased the state budget, it is necessary to know the information about the second and third group of carriers. Slovak carriers operating international freight transport, who could spend some of the amount of spent fuel pump in abroad, at a reduced rate, to be pumped in Slovakia and foreign carriers who would be in transit through our territory increased the amount of spent fuel. Each year, approximately removed to excise duty on mineral oils in SR $1104000000 €$. This amount is inclusive of gasoline tax, which we must deduct from the total amount, when we want to focus on diesel only, which is pumped by transport companies into semi-trailers or buses. Table 2 shows a relative redistribution, how much is the percentage of the mineral oil diesel oil and how much gasoline (Brueckner \& Fransler, 1983).

Table 2.

Revenue from excise duties for the Slovak Republic.

\begin{tabular}{|c|c|c|c|}
\hline Expression & Gasoline & Diesel & Income for mineral oils total \\
\hline In millions EUR & 460.368 & 643.632 & 1104 \\
\hline In \% & $\mathbf{4 1 . 7}$ & $\mathbf{5 8 . 3}$ & 100 \\
\hline
\end{tabular}

Source: authors by Statistic office SR

In our case, the amount is important $643632000 €$, which is assumed to have been achieved by the excise duty on diesel. The tax on diesel fuel is $0.368 € /$. Based on this rate, it was possible to find out, for which volume of liters of diesel fuel the amount is covered 643632000 $€$.

\section{$643632000 €: 0.368 € / I=1749000000$ I of diesel}

Volume 1749000000 I of diesel, represents the amount of diesel fuel that is pumped annually in the Slovak Republic. There is a certain amount of this diesel fuel \% volume diesel, which is pumped by vehicles over 7.5 tons, to which the reimbursement should apply. We need to know this percentage, how much diesel is used in transport, how much of this volume is used in road transport and also what volume of this is precisely the freight transport. The International Energy Agency publishes a summary report annually on the division of consumption of mineral oils according by the industry. Table 3 shows different industries, in our case, we will be interested in final consumption in the industry for the simulation of the refund "Transport" (Newman \& Kenworthy, 1999).

Table 3.

Distribution of final consumption of mineral oils by division.

\begin{tabular}{|l|c|c|}
\hline Final consumption & Mineral oil in $\boldsymbol{t}$ & Mineral oil in \% \\
\hline Industry & 16000 & 1.4 \\
\hline Transport & 1052000 & 91.8 \\
\hline Other & 78000 & 6.8 \\
\hline Summary & 1146000 & 100 \\
\hline
\end{tabular}

Source: authors by the International Energy Agency

For our refund simulation, it is important to know about this, that of the total consumption of mineral oils, was $91.8 \%$ used in transport, which represents the estimated volume in liters per year:

91.8\% from 1749000000 I diesel $\rightarrow \mathbf{1 6 0 5} 82000$ I diesel.

However, all types of transport are involved in this volume. We in simulation need to know only road transport, which can be deduced from Table 4 processed from the yearbook Transport of SR (Anas \& Rhee, 2006).

Among all types of transport in road transport, the largest share of diesel fuel in Slovakia is consumed. It is the total volume of diesel consumed in transport per year:

$88.1 \%$ from 1605582000 l diesel $\rightarrow \mathbf{1 4 1 4 5 1 7 7 4 2}$ I diesel. 
Table 4

Consumption of diesel fuel by mode of transport.

\begin{tabular}{|l|c|c|}
\hline $\begin{array}{c}\text { Type } \\
\text { of transport }\end{array}$ & $\begin{array}{c}\text { Consumption } \\
\text { of diesel fuel in I }\end{array}$ & $\begin{array}{c}\text { Consumption } \\
\text { expressed in \% }\end{array}$ \\
\hline Rail transport & 38007000 & 7.3 \\
\hline Road transport & 458798000 & 88.1 \\
\hline Inland waterway transport & 10614000 & 2.0 \\
\hline Secondary transport activities & 13397000 & 2.6 \\
\hline Summary & 520816000 & 100 \\
\hline
\end{tabular}

Source: processed by authors with the Slovak Transport Yearbook

Determination of the number of liters of diesel fuel used in road freight transport consumed by lorries over 7.5 tonnes:

Driving performance per year for RFT $\rightarrow 2729554635 \mathrm{~km}$

Average consumption of the lorry over $7.5 \mathrm{t} \rightarrow 0.32 \mathrm{l} \mathrm{km}$

Total consumption $\rightarrow \mathbf{8 7 7 0 9 1 1 6 5 ~ I ~ o f ~ d i e s e l ~ b y ~ r o a d ~ f r e i g h t ~ t r a n s p o r t ~ v e h i c l e s . ~}$

It follows from the total volume of diesel fuel, from which it will be transferred to the state budget of the Slovak Republic, excise duty is reversed 877091165 liters of diesel fuel pumped by road freight vehicles. What is a value $62 \%$.

Volume 877091165 I represents the total volume of diesel fuel, from which the excise duty is payable (from volume 1749000000 I), up to $62 \%$ of diesel fuel is pumped by freight vehicles. This amount would be subject to excise duty reimbursement, which could affect SR state budget.

Calculation of income to the state budget of the Slovak Republic following the introduction of the excise tax rebate:

Should Slovakia introduce a refund on excise duty on mineral oils the state would lose a certain amount of money from the state budget, which would be returned to the carrier. On the other hand, it would encourage the use of fuel in the Slovak Republic, where carriers would be more likely to pump on fuel than before. This chapter of this research tells us, how much \% should increase the consumption of fuel in Slovakia, that the state budget of the Slovak Republic should remain on the same revenues as before the introduction of the reimbursement.

$$
\begin{gathered}
\text { Tariff for trucks over } 7.5 \text { tons } \rightarrow 0.330 € / I \\
\text { Other rate } \rightarrow 0.368 € / / 877091165 I \cdot 0.330 € / I=289440084 € \\
871908835 / \cdot 0.368 € / I=320862451 €
\end{gathered}
$$

The total amount of excise duty collected, after the refund is introduced, represents a value $610302536 €$. The difference between the original value $643632000 €$, and the reduced value is $33329464 €$, which represents a decrease in SR about $5,2 \%$.

Calculating the required number of liters pumped by vehicles over 7.5 tons, that there should be no deficit in the state budget:

$$
3332964 €: 0.330 € / I \rightarrow 100998377 \text { I of diesel }
$$

If we want to achieve a simulation so that the same income will flow to the state budget of the SR from excise taxes every year, possibly larger amounts of funds, and to benefit carriers, undertaking in road freight transport by way of reimbursement, it is necessary to increase the amount of diesel fuel pumped into the Slovak Republic by the carriers, of the original ones 877091165 liters to 978089542 liters, which represents an increase of $100998377 I \rightarrow \mathbf{1 1 . 5 \%}$.

This means that if the current amount of fuel consumed by carriers in Slovakia is increased, performing international freight traffic by $11.5 \%$, excise tax revenue will not even change when we refund. Refund of excise duty will have an impact mainly on carrier costs. The rate at which these costs will be affected depends, in particular, on subject of the carrier's business, but also from many other factors, such as the diversity of transport destinations. 


\section{CONCLUSION}

Excise duty on mineral oils represents a significant revenue in the state budget of each EU country. There are states that support the policy of minimum rates of mineral oil tax on the use of fuel in their territory, thereby globally maximizing tax collection in the state budget. The increase in tax collection in these countries represents the fall in tax losses in other countries. For this reason, to increase the attractiveness of fuel consumption, especially diesel, EU member states are introducing a refund of the mineral oil tax. In the Slovak Republic, the tax refund system is not valid. Based on the research published in this paper would be effective for the Slovak Republic to refund the excise duty for vehicles over 7.5 tons of total weight, if the pump of these carriers increased by $11.5 \%$.

\section{ACKNOWLEDGEMENTS}

The contribution was elaborated with the support of the Ministry of Education of the Slovak Republic VEGA no. 1/0143/17 POLIAK, M.: Increasing the competitiveness of Slovak carriers providing road transport services in the common market of the European Union.

\section{REFERENCES}

Anas, A., Rhee, H.J. (2006). Curbing excess sprawl with congestion tolls and urban boundaries. Regional Science and Urban Economics, pp. 510-541.

Angelo, G.A. Faria. (1995). Tax coordination and harmonization. In: S. Parthasarathi, Tax policy handbook. Whashington.

Ayala, D., Wolfson, O., Xu, B., Dasgupta, B., Lin, J., (2010). Pricing of parking for congestion reduction. Proceedings of Sigspatial/GIS, pp. 43-51.

Balko, L., Králik, J. (2005). Finančné právo. I. čast'. Bratislava: Univerzita Komenského. Právnická fakulta, pp 308.

Brueckner, J.K., Fransler, D.A. (1983). The Economics of urban sprawl. The Review of Economics and Statistic, pp. 479-482.

Brzeziński, B., Gluchowski, J., Kosikowski, C. (1998). Harmonizacja prawa podatkoweho Unii Europejskej i Polski, pp. 313.

Casana, M., Alvárez, A. (2001). Tributos locales, Edersa 2002, European commission: Inventory of taxes in the EU, United Kingdom.

Faria, Angelo G.A. (1995). Tax coordination and harmonization. In: Tax Policy Handbook. Ed. By Parthasarathi Shome, IMF.

Frumkin, H., Frank, L., Jackson, R. (2004). Urban sprawl and public health. Washington: Island Press.

Gnap, J., Cajchan, J., Šulgan, M. (2003). Measuring methodology form real bus-stop distances of public passenger transport. Jan.

Kosikowski, C. (2003). Podatki konsumpcyjne. In: C., Kosikowski, E. Ruśkowski, eds., Finanse publiczne i prawo finansowe. Warszawa: Nakladateství Dom Wydawniczy ABC.

Kubátová, K. (2006). Daňová teória a politika. 4. aktualizované vydanie. Praha: ASPI a.s., pp. 279.

Newman, P., Kenworthy, J. (1999). Overcoming automobile dependence. Sustainability and cities, pp. 442.

Poliak, M., Poliaková, A. (2015). Relation of social legislation in road transport on driver's work quality. Tools of transport telematics. Wroclaw: TsT, pp. 300-310.

Walters, A.A. (1968). The economics of road user charges. World Bank Staff occasional paper. Baltimore: John Hopkins Press. 